\title{
The Cult of Exchange Value and the Critical Theory of Spectacle
}

\author{
Mark P. Worrell
}

The concept of 'spectacle' entered the vocabulary of the social sciences with the publication of Debord's classic Society of the Spectacle. Debord and company were concerned with art, aesthetics, urbanism, the city, architecture, and so on, but, as Lefebvre points out, as these multiple concerns fell by the wayside the Situationists were left with generally little more than an abstract critique of society and polemics (McDonough 2002: 275-76, 281) with the notion of spectacle at the center of it all. To the extent that Situationism still exerts an influence on critical theory it is apparently in just this notion of spectacle. But what does it mean, really? Once anyone evokes the S-word it typically unleashes a torrent: here a spectacle, there a spectacle, everywhere a spectacle. I argue that Debord's formulation of spectacle, despite its vague and multiform meanings, has more specific implications regarding a deeper comprehension of the Marxist theory of alienated social relations and that thinking of spectacle along the lines of expanding the concept of alienation and the value form will salvage this concept from a fate of signifying everything, and, thereby nothing. I want to draw out and contrast three meanings of spectacle here: first, and completely commonplace, the notion that commodification has become ubiquitous and image-driven; secondly, and much less banal, the double density of alienation found in spectacular social relations; and lastly, how spectacle comprehends the logic of reclaiming and sacralizing margins and waste. Along the way we will examine a wide array of phenomena such as doll collecting, competitive eating, upcycling, and, NASCAR to highlight the peculiar logic of spectacle society.

\section{Consumption and Image}

The idea of exchange and commodity ubiquity reveals that social and private space is reorganized by the logic of exchange as a form of seamless exploitation at the service of capital accumulation. Action is here reduced to routinized mass consumption - a notion that would have been familiar to Horkheimer and Adorno ([1944/1947] 1972: 28); human relations assume the logic of commodity circulation. "Even tourism" says Gombin, "imitates the circulation of commodities - the package deal, the predictable routes, and the artificial entertainments" (1972: 39). The vacation resort is typical:

\footnotetext{
[W] hen we arrived at the hotel we were received graciously: wreathed in orchid leis and encouraged to help ourselves to cups of tasty iced guava juice. Only much later, while reading some very fine print, did I learn that we had actually bought both treats. The sixteen-dollar-a-day "resort fee" covers one lei greeting per guest and a "Welcome Mai Tai punch (nonalcoholic)."[1] Our room was like a little shop. In addition to the standard mini-bar setup, there was a basket of sun-tanning products (seventy dollars), shrink-wrapped bottles of Evian, playing cards, and children's shampoo for sale. We begged the kids not to touch any of the merchandise (Flanagan 2005: 38).
}

Setting aside the interesting logic of children imprisoned in a cage of sumptuous taboo objects due to their lack of commercial authorization, the same logic obtains on many airline flights. Now, flying from, say, Houston to Oahu is not merely a 'flight' in the traditional sense (motion combined with peanuts and cinema) but a shopping 
spree where passengers can enjoy 'duty free shopping' from a catalog - airplane qua 'Sky Mall.' Here, 'Social life is shattered into an ensemble of hermetic points for the purpose of organizing a higher unity, that is, the analytic arrangement of experience that capitalism requires for its smoothest operation" (Ball 1987: 27). Connected to this ubiquity of commerce is the notion of the image-centric nature of exchange: "The commodity used to be a material thing; now it is a spectacular event. The spectacle is the commodity that has left its material body on earth and risen to a new ethereal presence. One does not buy objects; one buys images connected to them. One does not buy the utility of goods; one buys the evanescent experience of ownership. Everywhere, one buys the spectacle" (Ball 1987: 28). This all sounds rather exotic but one has to look no further than Durkheim's Elementary Forms for an even more penetrating analysis of the effervescent signifier. This connection between object and image is commonplace and central to our current notions of themed experiences, total commodification, reduction of all events into entertainment, etc. But this is not the limit of spectacle.[2] The common reading of spectacle advances little beyond the naive interpretation of spectaculum ('public show') and misses the inner theology of its root, specere ('to look'), whereby subjects project and recognize the enchanted fabric of nature and life. This second meaning of spectacle, the double density of alienation, will take us into a more complicated, interesting, and colorful realm. To grasp the relationship between spectacle and the peculiar nature of alienation, we need to first briefly review Marx's theory of the commodity.

\section{Marx's Theory of the Commodity}

Anyone who has paid careful attention to Marx's critique of the commodity and value forms can instantly see that Society of the Spectacle was intended to represent the theoretical extension of exchange value beyond those forms that Marx outlined: accidental, expanded, general, and money. To these now-familiar forms we would want, after Debord, to add spectacular to the phenomenological sequence. Spectacle represented, so it would seem, a dialectical leap into a new fetishism form where commodities, money, and capital performed the impossible feat of slipping free from use-values and persisting beyond the constitutive exchange relation. Think of spectacle as literally persistent post-exchange value. Of course, the notion of post-exchange value is not real but value beyond exchange is also not real in the same way that ghosts and devils are not real: even as fantasies they nonetheless possess the capacity to plague the imagination. Intending "to go further than Marx" (Gombin 1972: 41) Society of the Spectacle represents an elaboration on Marx's analysis of the money form but it remains to be seen whether adding 'spectacle' to the value form sequence is warranted. It depends upon what we mean (and what Marx meant) by 'value' - what is value?

After providing a competent summary of Marx’s theory of the commodity Webber and Rigby (1996: 99) make the following assertion: "Commodities then are those things that store objective value: value is a property of some kinds of commodities. A commodity is a thing that stores objective value." Here, the authors want us to think that commodities have value. We know from Marx that value is a form of collective thinking whose foundation is abstract labor: not an atom of material enters into it.[3] The commodity does not represent a preservation or storage function whereby the property or material of value is held within the body of a utility; [4] rather, the exchange relation confers upon a utility the social status of being a value. When we talk of the "objectivity" of value we only tell half the story: the objectivity of value is an "abstract objectivity - a thing of thought” (Smith 2001: 58) or, in Marx's words, a "sublime objectivity." And Marx said all this himself: there is no such thing as value beyond the exchange relation; there is, in other words, no value an sich (1976: 152).[5]

What Debord conveys with the idea of spectacle is the extent to which the logic of exchange has penetrated into everyday consciousness at precisely the point where the equivalent value form (money) itself dissolves into abstraction; the extent to which exchange value has become literally disembodied or spectral. As money becomes increasingly abstract its fetish power is magnified: "When, in a decade or so, money will finally become a purely virtual point of reference, no longer materialized in a particular object, this dematerialization will render its fetishistic power absolute: its very invisibility will render it all-powerful and omnipresent" (Zizek 2008: 35). Pushed to extremes spectacle is the belief in value disembodied, resistant to stable forms, free from earthy bonds, colonizing the totality of the social universe; every word spoken through us is the voice of commerce and exchange, warped by the distortion field of omnipresent and omnipotent exchange value; every visual or acoustic image we see or hear (the whole signifying chain in which we are submerged) is dictated by the logic of alienation and exchange; there are no 
longer relations or thoughts not colored by the dictates of value; spectacle society is the absolute realization of not just commodity relations but the deification of value; people now have prices in their eyes, money on their minds, commodities in their dreams, and, in the case of the lucky few, capital in their veins. Debord presents us with a map of impossible worlds: all relations, all non-relations, all time, all space, all forms and non-forms swimming in exchange value or, really, particular manifestations of universal value; spectacular society marks the final and total ascendancy of exchange value. This condition was what Debord later called the "integrated spectacle" in which "The spectacle has spread itself to the point where it now permeates all reality" (1988: 9).

In societies that have reached the stage of the integrated spectacle, history, criticism, direct experience, truth, real facts, and substance have been extinguished. The integrated spectacle is an extreme idea (that we are now incapable of existence outside the cage of value) but it is empirically true that people living in capitalist societies act, think, and feel to a very great extent as if they were essentially members of a cult - the cult of exchange value. Debord was definitely on to something but the world of the integrated spectacle was a world where "all" and "every" could be used with a straight face. Spectacle and the integrated spectacle were, in Weberian terms, ideal types (sociological caricatures). Empirical reality is never as air tight as Debord's construction suggests. No totalitarian social order is perfectly seamless in its capacity for subjective and objective domination - indeed, what would be the point of "situations" if that were true? The sociologically relevant questions are: how, why, and to what extent did empirically existing phenomena deviate from the theory of the spectacle and to what extent do some social relations and institutions approach the ideal type of spectacle.

\section{| Doll Collecting and the Double Density of Alienation}

Spectacle means permanent and enjoyed alienation, alienation without end, alienation on top of alienation: alienation twice over (at least). In other words, spectacle forces a reversal of consciousness such that the consumer adopts the position of the seller. Let's consider, first, an anecdotal example of a doll collector named Al Trui. Mr. Trui's collection is preserved in just the condition in which the pieces were originally bought and housed in his residence made to look and feel, in many respects, like the original point of purchase. His doll collection and collecting logic goes beyond the typical forms of collecting (and beyond the normal form of "collector value").

Contrast $\mathrm{Al}$ Trui's perfect and pristine preservation of his dolls with the conduct of other collectors - trading cards for example. Generally speaking, trading cards (e.g., sports cards) are sold in packages that are opened, the cards are sorted, and prized specimens are segregated and housed in special containers. Unlike Trui's dolls, the card collector generally does not preserve his or her object as it existed at the moment of exchange. Some preserve unopened packages of cards but as far as I know the norm in card collecting is still to open the packaging because the nature of card collecting is such that the contents are mysterious.[6] Typically packaging is violated (reduced to waste) because anonymity is not the norm. Even when the packaging, the shell, is preserved what is missing is the preservation of the exchange moment - the time and space of exchange. Spectacle moves us beyond "normal" collector fetishism.

The logic of spectacle is to transform everyday reality into the fiction of the perpetual and never-ending moment of exchange - to preserve the exchange experience beyond exchange. Al Trui's "living room" literally takes on the nature of a retail outlet. Walking into his apartment is like walking into a section of a toy store. In this "store" the price tags are left on the packaging (and, of course, the packaging, far from waste, is preserved). Where a price tag normally creates a moral force field (a prohibition) protecting commodities located in the marketplace, spectacle represents the preservation of prohibition beyond the threshold of exchange - whereby the consumer protects his or her goods from the self as well as others. If alienation means, in a sense, forgetting, spectacle forces upon us an extended or perpetual forgetting, the doubling of forgetting, perpetual forgetting - as with $\mathrm{Al}$, he must continue to forget, daily, that he ever actually paid for his dolls or that he ever left the shop. His dolls forever exert a kind of dominion over him by virtue of a hold, the embrace of (purely fictional) exchange value. To forget to forget (to renounce alienation) would leave open the catastrophe of use-enjoyment, which would be, from the standpoint of spectacle, no real enjoyment at all (useless-enjoyment, i.e., real enjoyment).

If Mr. Trui succumbed to the temptations of use (and what use could a doll be to Al?) then his doll would be polluted and have no attraction for him. He would literally have no use for it even though, of course, all that it has to offer would be use. But the doll is useless to begin with. Which points to another aspect of spectacle: the doubling 
of uselessness. Commodities are, from one aspect, automatically useless - for the producer who possesses a surplus of dolls, they are useless as far as their use-values go (doll producers do not need dolls as dolls but only as material props to attract surplus value). Being for sale presupposes uselessness. And in the case of $\mathrm{Al}$ Trui he renders the doll useless by making it unavailable to himself - here, utility is merely a condition for continued seduction. In not using his dolls $\mathrm{Al}$ preserves the uselessness of the commodity in its relative form, assuming the mentality of the seller but, simultaneously, preserving the consumer experience by converting his apartment into a point of purchase. Spectacle is the guarantee of desire for the sake of desire where the reduction of a thing to a use-value renders it useless. Therefore, we find the paradoxical nature of spectacle: double uselessness. The dolls must remain unused (useless) or suffer the fate of becoming "useless" (they only look like dolls). And since Al is prohibited from use of his doll then he must acquire more to fill the void of utility created by spectacle. With this doubling of uselessness Mr. Trui places himself in the position of the manufacturer (qua property owner) who is not permitted to enjoy the utility of the labor product but also the consumer who preserves the fiction of value by preserving the moment of exchange.[7]

Spectacle, as enjoyment, is enjoyment by non-enjoyment or, the same thing, enjoying non-enjoyment. Mr. Trui's enjoyment of his doll collection is predicated on this kind of deferment of enjoyment and the enjoyment of deferment. It is the putting off today what will be put off tomorrow and the next day that supports the belief that the effervescence of the exchange moment will endure forever. Spectacle amounts to the same thing as abandoning one's home to live in a retail outlet - just as Al's's collection only looks like dolls, his living room is actually a toy store that looks like a living room. Though, even here, the most exotic limits of the spectacle have not been reached; indeed, the true perversity of the spectacle (the fetish absurdity of post-exchange value) is the perpetuation and transformation of the post-exchange exchange relation (since it "as if" it has never ended) between the buyer and his or her goods: in the case of $\mathrm{Al}$, his dolls assume the position of the relative value form vis-à-vis his position as the universal equivalent.[8]

Literally, in this world as freakish as science fiction, the "members" of the doll collection each look over their shoulders at the utility form in which their value (and moral status) is embodied, namely Al, the "owner" of the dolls just as if a real exchange relation between linen and coats were under consideration. As such, these dolls "have value" insofar as he occupies the coordinates of their universal equivalent - the preservation of our monetary social form into the purely private sphere of life such that private life beyond the horizon of exchange value and money evaporates altogether. Al Trui, here and impossibly, assumes the social form of the fictional relative commodities. The dolls' social form, in other words, is Al himself. At first glance, the owner, appears to occupy the master's position in this relation until one realizes that he actually assumes the responsibilities of a slave - to break the embrace, his dolls would be cast into the void of mere use and what would Mr. Trui be relegated to? Of course, this embrace is enjoyment until the collection is completed at which time "collecting" terminates; the prison sentence ends in parole. But, of course, the collection can never find completion.

Spectacle is a form of consciousness whereby the typical relation of buyer and seller is disrupted. With Marx we have a seller who is interested in the other's money and a buyer who has his or her eye on the use value of the seller's items - the relative and equivalent value forms are, of course, perspectival. What Debord was getting at was a curious mode of consciousness that we could describe as total or dual-density alienation - alienation twice over if not more. Not only the seller alienates his or her labor product reducing it to a one-sided abstraction but the buyer too embraces the object of desire in the exchange as a pure abstraction - a mere quantitative form to be enjoyed as a quantitative instance. This is the same logic of any collector who must accumulate not this or that card but the entire, quantitative sequence. Only upon "completion" (impossible) does the mass redeem the particular. But since the horizon of the total collection is constantly in motion the redemption is forever deferred - per Hegel's Philosophy of History, the collector, who would appear to be devoted to the particular, conforms to the logic of the "fanatic", one devoted to the abstract.

With Mr. Trui, a single doll is useless until he has acquired all the dolls possible (a complete set). It's "use" is to be "useless" until the fictional yet logical moment when "all" the dolls are collected - in which case the entire collection would become what it is, namely, "useless" (due to its completion); what could be more useless than a completed collection? Then what? If Mr. Trui could conceivably complete his doll collection then we would be justified in concluding, with Lacan, that $\mathrm{Al}$ must not have really wanted the dolls anyway. And if a total set could be completed then they are instantly reconstructed as a mere subset of a larger universe of doll sets - hence, guarantying the impossibility of ever completing a collection. As we saw above, completion would reduce the dynamic action of collecting dolls to that of a mere prison sentence whereby we mark time in order to preserve the existence of fictional value for our others - people reduced to placeholders for the enjoyment of our collections (i.e., the 
collection's enjoyment). That is, the dolls enjoy Al's devotion. Completion would short-circuit this desire of desire. And, as we saw earlier, if it is true, in the commonplace sense, that "One does not buy objects; one buys images connected to them" (Ball 1987: 28) then the truly spectacular effect is how a mere image affixed to a "perfectly good" utility can render its usefulness perfectly useless. This is the special, automatic and deadly function of spectacle. That consumers purchase images, symbols, signifiers, and logos, et al, is completely beside the point - what is sociologically interesting is the struggle to construct the grace (or disgrace) of images in order to specifically destroy the underlying utility of a perfectly good utility: virtual consumption in the absence of actual consumption. Of course, the truly spectacular moment is not the virtual destruction of an underlying use-value but the rebirth of uselessness in the form of irony: e.g., vintage clothing market. But then this, too, does not reach the truly spectacular: the manufacturing of faux vintage (distressed) clothing bearing new logos.

In the war of signifiers where utilities are open to symbolic negation and moral uselessness, we find that firms, now, as did the true disciple of Christ in the past, “...waste...as God does in nature and history, in creation and salvation" (Tillich 1955: 48).[9] At this point the anecdotal episode of Al Trui and his doll collection reveals a new avenue through the conceptual maze of spectacle: the double suspension of use values as necessary props for the appearance and persistence of unreal values.

\section{Uselessness Value and the Reclamation of Waste}

As Marx says, a commodity must possess a use-value in order to serve as the substratum of exchange-value. Yet, in spectacle society, we find, literally, uselessness as one possible foundation for exchange-value.[10] There is a definite theoretical extension, here, beyond Marx's classical analysis of the commodity and the capitalist mode of production.

Waste is a conspicuous feature of capitalism: time and energy leak out of the organic composition of capital and the labor process like a sieve. The history of management is the history of waging war against waste: laziness, traditionalism, inefficiency, etc. Technical rationalization of the means of production compresses time and space to reduce waste but waste is, in the final analysis, an inherent feature of capitalist production - or any kind of production. And, of course, waste also occurs when goods go unsold, spoil, etc. In short, it used to be that industry confronted the problem of disposing of waste[11] and then reducing waste. Spectacle represents, in one sense, the transformation of waste (uselessness) into exchangeable surplus and the consumption of uselessness.[12] Competitive eating, upcycling, and NASCAR are each appropriate illustrations of the "uselessness-value" of spectacle.

\section{Competitive Eating}

"Seeing these guys go at a 20 pound turkey is like poetry", says the chairman of the International Federation of Competitive Eating, the organizer of more than six-dozen eating contests per year. The "fastest growing sport" in America is a prime example of scraping up marginal waste like hotdogs (lips and tails) and placing them at the center of an orgiastic ritual of hyper-consumption (championship performance requires the eating of approximately 50 hotdogs in twelve minutes (Nerz 2006).[13] As Fagone puts it, competitive eating is literally a way for the marginal members of competition society to excel in a spectacle world (2006) - surplus population ritually consuming waste and transforming themselves from 'nothing' or 'nobody' into representations that allude to comic book heroism: "The Black Widow" and "Eater X." Spectacle society is one in which each person, regardless of their weaknesses, can aspire to champion status. Spectacle means that nobody is left out or excluded from consumption and virtuosity. The essence of competitive eating is turning backcountry, county fair bumpkin fun into international competition with prizes in the hundreds of thousands of dollars.[14] Of course, the extended spectacle comes in the form of parodying and 'professionalizing' the event such that no longer place marginal waste like hotdogs at the center of the orgy but any and all types of food; the record for tamales, for example, is 71 in 12 minutes and a person would need to eat 28 cannoli in 6 minutes to hold the title.

\section{Upcycling}

Normal recycling and waste reclamation only hints at the logic of spectacle. As in the case of hotdogs, reclamation results in a low-quality, cheap product for non-discriminating consumers. Upcycling, on the other hand, takes waste and converts it into high-quality products for snobs - or at least, something that is of higher 'value' 
than the sum of its parts (McDonough and Braungart 2002).[15] Inverting the logic of found art or the Dadaist conversion of, say, a urinal into art via charisma transfer (adding all-new connotations to the phrase "royal touch") spectacular upcycling relies on the impersonal transformation of trash into value - of its own birth, so to speak, a free gift of grace - holy waste.

\section{NASCAR}

NASCAR evokes the image of cars racing around a track surrounded by hordes of spectators yet the truth is that a NASCAR track is a useless black hole exerting a magnetic commercial effect on the surrounding region.[16] I lived in the shadow of the Kansas Speedway, a colossal racing complex in Kansas City, Kansas and I was amazed at the sheer quantity of nothingness that went on there yet it was unrelenting in transforming the surrounding scrub brush into NASCAR-themed outlets, restaurants, hotels, etc. And, decisively, not only does the "thing" draw in businesses but the residential areas around "it" are transformed into parking and "mom and pop" novelty stands. It mobilizes everybody and, even for the NASCAR atheist or naysayer, NASCAR gives freely of itself, like holy dispensation: your home and property "values" (really prices) double the moment NASCAR announces the impending arrival of a track in your area. How much "nothing" can NASCAR deliver to your town?

A glance at the 2008 event calendar for the Speedway reveals a massive amount of inactivity: four races over two weekends: “Kansas Speedway's exciting, 2008 Ticket package - a season ticket that includes admission to events over two weekends. This ticket package is a race fan's dream. Stock cars, tough trucks, and Indy cars make up one of the most diverse track schedules in the country." Oh, the stuff of dreams. This is spectacularism at its purest: take cheap, underdeveloped land in a derelict part of town, spend tens of millions creating a massive, NASCARthemed complex that awakens from hibernation a few days a year, yet reorganizes the entire zip code around the myth of NASCAR: NASCAR-ism - out of nothing, the genesis of an imaginary world encrusted by thematically synchronized businesses and residents. The imaginary or mythical "race" lures people into its gravitational field and, since there's nothing going on there, leaves them free to consume food, beds, computers, cars, etc. The micro logic of the collector and his useless dolls, here, lives out its dream at the most aggregate level of regional commercialism predicated upon the promise of everything and the delivery of virtually nothing.[17]

\section{Conclusion}

In Marx's Capital, devotion to the abstract and the fetishism of the commodity assumes a generic, serial quality that resonates well with Durkheim's analysis of anomie and the frenzy of consumption. Yet, the move to the spectacle à la Debord resembles less the 'infinity of desire' found in Suicide and more the logic of the totem qua social form in Elementary Forms. For both Marx and Durkheim, identity-in-difference and alienation (negation and doubling of the self) formed the bases of subject-object identity, yet, it is Durkheim (the unacknowledged elephant in the room of much French critical theory) that truly unravels the mystery of the spectacle as cult and, metaphorically, a kind of 'neo-totemism.' If spectacle was reducible to the standard theory of the universal equivalent writ large across the social panorama we could move no further than purely quantitative determinations. Spectacle, in essence, looks backwards to a pre-modern 'mentality' all the while the universal equivalent dissolves into total abstraction - activating a never-ending, self-generating series of anxious cults, including liberal, multicultural nihilism and the intellectually debilitating Nominalism of deconstruction. "There is," says Zizek,

... another mode of anxiety which predominates today: the anxiety caused by the claustrophobia of the atonal world which lacks any structuring 'point,' the anxiety of the 'pathological Narcissus' frustrated by the fact that he is caught in the endless competitive mirroring of the fellow men (a-a'-a"-a"' ...), of the series of 'small others' none of which functions as the standin for the 'big Other.' The root of this claustrophobia is that the lack of embodied stand-ins for the bit Other, instead of opening up the social space, depriving it of any Master-figures, renders the invisible 'big Other,' the mechanism that regulates the interaction of 'small others,' all the more all-pervasive (2008: 36).

Undoubtedly, in the final analysis, the spectacle of NASCAR is encompassed within the trajectory and accumulation of exchange value but its social logic (the means to that end) is far more encompassing than the reduction of relations to sheer magnitudes. In the mana world, humans were 'reduced' to their totemic identity (perhaps a white cockatoo)[18] and in NASCAR we see consumers rallying around a collective ('positive') social 
form quite distinct from the egoistic pleasures of 'normal' commodity fetishism. Doll collecting, in other words, represents (in the case of our collector) the embryonic form of spectacle because it fails to work itself out in the company of the shameless other (an epicurean-egoistic spectacle). NASCAR represents the spectacle as it is fully worked out to the point where the self-conscious and potentially embarrassed consumer is transformed into the shameless rube driving a replica racecar to the grocery store or wearing a leather racing costume to a parent-teachers conference. Truly, a spectacle.

\section{Endnotes}

1. "On today's market, we find a whole series of products deprived of their malignant properties: coffee without caffeine, cream without fat, beer without alcohol.... And the list goes on: what about virtual sex as sex without sex, the Colin Powell doctrine of warfare with no casualties (on our side, of course) as warfare without warfare, the contemporary redefinition of politics as the art of expert administration, that is, as politics without politics, up to today's tolerant liberal multiculturalism as an experience of the Other deprived of its Otherness..." (Žižek 2002: 10-11).

2. Moreover, this presentation only covers the 'positive' phase of spectacle. The 'other side' of spectacle is not the multiplication of purchase points but the multiplication of points whereby people donate increasing quantities of unpaid labor (e.g., the customer service fetish in our universities; self-service outlets; self-checkout in grocery stores; customers bussing their own tables; customer-generated online content such as 'reviews', musical lessons, etc., and 'news' content donated by viewers and distributed online by the likes of $\mathrm{CNN}$, etc.

3. "It is the essential character of Nature to sacrifice itself, to consume itself, so that the Psyche comes forth out of this burnt-offering and the Idea rises into its proper element, into its own ethereality. This sacrifice of Nature is its process.... The moments, through which the Idea runs its course in the web or garment of Nature, are a series of independent forms. Nature is the Idea potentially, and only potentially, and the peculiar mode of its existence is to be outside of itself, in perfect externality. The nature of its progress is, more chiefly speaking, this, that the Notion which is enclosed in it breaks through its covering, absorbs the outer crust of its externality, idealises it, and while rendering the coating of the crystal transparent, is itself revealed to view. The indwelling Notion becomes external, or conversely, Nature immerses itself in itself, and what is external constitutes itself a mode of the Notion.... This is the truth of Nature, namely, Consciousness" (Hegel [1840] 1974: 109-10).

4. Carchedi provides a typical and recent example of the fetish expression of value: "Upon its completion, a commodity contains value, crystallized human labour in the abstract. This is its individual value, a realized substance. But this is not the value that commodity realizes upon its sale, its social value. The commodity can realize more or less than its value contained or even nothing at all, if it is not sold" (2008: 497). First, "upon its completion, a commodity contains value..." What do we mean by 'completion' exactly? A commodity is never 'completed.' A labor product is completed but a commodity is a labor product that is brought into an exchange relation with another commodity. Here we find a reified conception of the commodity. A formulation such as 'the completion of the commodity' is meaningless. Second, commodities do not 'contain' value - value is abstract labor (more accurately, it is socially necessary quantities of abstract labor) so value can never be contained just as words do not 'contain' meaning. If something can contain value then it can do so independently and outside of a relation with its equivalent other. Third, Carchedi allows for the misplacement of value as a purely social phenomena when it is claimed that there are individual values or values in themselves, This is a Kantian regression back to the thing in itself. Mauss provides us with a relevant notion apropos the misplaced object of analysis: "Once engaged in science, [the individual] is aware of things in and for themselves, rather than feeling them exclusively in relation to himself and to his acts, or of representing them in a kind of magic mirror, in relation to mythical images, sometimes useless ones" (2005: 50).

5. I chose the earlier passage from Webber and Rigby not because they offered an idiosyncratic or atypically absurd interpretation of Marx's theory but because they put forward a common reading whereby value assumes an existence beyond the exchange relation. This hypostatic interpretation is precisely what Debord described as symptomatic of modern social life - value off its tether, released from its social and relational moorings. In other words, if Webber and Rigby are correct than the Discovery Channel is equally correct when they characterize the Great White shark as a devilish engine of death. In this "cult" the logic of exchange permeates "every" nook and cranny of space and time. The spectacle concept attempts to theorize this fetish form and is comprehended within the perverse logic of double alienation. As noted above, though, value must take a form and we need to elaborate on the idea of forms before proceeding.

6. Unopened packs of cards from the 1950s through the 1970 s are considered the holiest of holies in the cardcolleting realm due to their rarity. Here, collecting 
interests with speculation; high prices are demanded for unopened packs of cards even though they are not guaranteed to contain 'stars' or relatively 'valuable' cards. One simply assumes the risk and hopes for the best - which might explain why a buyer of unopened packs would keep them unopened and preserve the mystery and their 'value.' The wrapper, which would normally be waste, here, preserves 'value.'

7. The spectacle logic, here, is an extension of the classical formulation put forward by Simmel: "people pile up precious collections of any kind without getting any satisfaction from the objects themselves, frequently without even caring about them. In such cases, value is located not in the subjective reflex of ownership that is normally the reason for acquisition and possession, but in the simple objective fact, unaccompanied by any personal consequences, that merely having these things in their possession is valuable for such people." Simmel locates this logic in the egoistic impulse to deny ownership to others. "The collector" he continues, "who shuts away his valuables from everyone else and who does not even enjoy them himself, yet watches most jealously over them, colours his egoism with an admixture of supra-subjective valuation....the true motivation is the fact of its being possessed, the form of the relationship in which the subject stands to the object" (1990: 23940). But, from the standpoint of spectacle, and as we will see later, the relational moments would be inverted from the classical formulation: the key is not to be in possession but to be possessed, to be a receptacle, as it were, for the holy spirit, value.

8. This also points the way to regression in established value forms. In chapter one of Capital we see the progression of value from the accidental on out to the money forms. But exchange relations can and do regress into alterations of previous forms - in the case of disaster economies, for example, where fuel and water, e.g., function (as money can not) as the polycentric core of a general value form; in the case of hurricane Katrina, e.g., we witnessed the temporary operation of the regressive polycentric general value form. In the case of Al Trui's doll relation we also find a value form regression of sorts.

9. Tillich's sermon "Holy Waste" is truly brilliant in situating waste, utility, and alienation. "Has not Protestantism not lost a great deal by losing the wasteful self-surrender of the saints and the mystics? Are we not in danger of a religious and moral utilitarianism which always asks for the reasonable purpose - the same question as that of the disciples of Bethany? There is no creativity, divine or human, without the holy waste which comes out of the creative abundance of the heart and does not ask, 'What use is this?"' (ibid.).

10. There is an intersecting logic, here, with "useless" entertainment hitched to advertising revenue: for example, the absurdity of television programming marketed to the mechanized peasantry of Idaho in which they learn all the ins-and-outs of surviving an airplane crash in the Amazon.
11. "Every great factory has, to-day, its by-products. The art of disposing of the waste materials of the principal industrial operation is becoming an integrant part of the profession of the commercial engineer" (Bougle [1926] 1970: 86).

12. Above, we saw how spectacle logic also reduces perfectly good use values to uselessness through symbolic assassination necessitating further consumption of what would otherwise have been uselessness.

13. During the summer of 2008, Joey Chestnut consumed 59 hotdogs in 10 minutes for a new world record. He also holds a record for eating 45 slices of pizza in 10 minutes as well as 93 hamburgers in 8 minutes. "Man Eats 45 Slices of Pizza in 10 Minutes to Win Contest" (http://www.cnn.com/2008/US/10/12/ pizza.eating.contest.ap/index.html).

14. The chairman of the IFCE insists "competitive eaters are athletes who train for their sport, working to improve jaw strength and increasing their stomach capacity. This is an entertainment product that has its roots in fairs and festivals and not a celebration of excess.... It's a comedic thing - a combination of Coney Island hucksterism and sports commentary" ("Ups and Downs of Competitive Eating", November 21, 2007: www.cnn.com/2007/LIVING/wayoflife/11/21/ eating.contests.ap/index.html).

15. Penelope Green, "Romancing The Flat Pack: Ikea, Repurposed," The New York Times, September 6, 2007.

16. Special thanks to Dan Krier (Iowa State University department of sociology) for insight into NASCAR operations and the connection between racing and spectacle.

17. Spectacle distorts not only exchange but also the world of work. In the late Fordist epoch (roughly 1945 to 1970) the drive to destroy craft labor was taken to extremes such that the dream of reducing laborers to interchangeable units of generic, low-skilled, labor power was, if not achieved totally, then none the less realized to a significant degree - even where skilled labor survived, the presence of actual praxis was in no way guaranteed and, indeed, rare. Within the Fordist system the production of genuinely craft or artisan products was limited to the private sphere. Henry de Man, writing in the early Fordist period, observed: Thwarted creative impulse will, in exceptional instances, lead a skilled workman to practice his craft in artistic freedom out of hours. For instance, a joiner whose work at the shop is mechanized will, in the evening, make desks with secret drawers or similar useless though highly finished trifles, merely to please himself (de Man [1928] 1985: 54). Spectacular work involves all manner of perversities and inversions such as artisanship and small-batch, boutique production (emerging in part from the decomposition of vertically integrated firms during the 1980s and 90s) dedicated to producing things modeled after Fordist-era, massmanufactured commodities. For example, within 
the musical instrument sector, especially guitars, one finds a bewildering number of high-value instruments, hand-built by artisans, but corresponding closely to cheap, assembly line, slab wood and stamped metal instruments, from the $50 \mathrm{~s}$ and $60 \mathrm{~s}$. It seems that in many cases, the closer a boutique builder can approximate the original Fordist-era guitar (not infrequently this includes distressing or 'relicing' the guitar to approximate decades of careful but continuous use) the greater the perceived value. And here, with 'relicing', craftsmanship takes another bizarre turn: one must cultivate skills in creating the illusion of diminished utility that simultaneously increases the value of the guitar - increased exchange value but also greater 'fetish value.' Just as NASCAR operates as a kind of return of the 'totem', spectacle work is constantly oriented to the past.

18. 'Reduced' in the Latin sense (reductio) from reducere (to 'bring back' or 'restore'). Negation of self means not only cancellation (leaving behind a remainder or lack) but also restoration, i.e., assuming the form of a 'surplus.'

\section{References}

Ball, Edward. 1987. "The Great Sideshow of the Situationist International.” Yale French Studies, 73: 21-37

Bougle, C. [1926] 1970. The Evolution of Values. New York: Augustus M. Kelley.

Carchedi, Guglielmo. 2008. "Logic and Dialectics in Social Science, Part I: Dialectics, Social Phenomena and NonEquilibrium." Critical Sociology 34(4): 495-523.

Debord, Guy. 1988. Comments on the Society of the Spectacle. London: Verso.

Debord, Guy. [1967] 1983. Society of the Spectacle. Detroit: Black \& Red.

Durkheim, Emile. [1897] 1951. Suicide. New York: Free Press.

Durkheim, Emile. [1912] 1995. The Elementary Forms of Religious Life. New York: Free Press.

Fagone, Jason. 2006. Horsemen of the Esophagus. New York: Crown.

Flanagan, Caitlin. 2005. “The Price of Paradise.” The New Yorker (January 3): 36-41.

Gombin, Richard. 1972. "French Leftism." Journal of Contemporary History 7(1/2): 27-50.

Hegel, G. W. F. [1840] 1974. Lectures on the Philosophy of Religion, Vol. 1, trans. by E. B. Speirs and J. Burdon Sanderson. New York: The Humanities Press.

Horkheimer, Max and Theodor W. Adorno. [1944/1947] 1972. Dialectic of Enlightenment. New York: Continuum.

Man, Henry de. [1928] 1985. The Psychology of Marxian Socialism, translated by Eden and Cedar Paul. New Brunswick: Transaction Books.
Marx, Karl. 1976. Capital, vol. 1, translated by Ben Fowkes. New York: Vintage.

Mauss, Marcel. 2005. The Nature of Sociology, translated by William Jeffrey and edited by Mike Gane. New York: Durkheim Press / Berghahn Books.

McDonough, Tom (Editor). 2002. Guy Debord and the Situationist International: Texts and Documents. Cambridge, Massachusetts: The MIT Press.

McDonough, William and Michael Braungart. 2002. Cradle to Cradle: Remaking the Way We Make Things. New York: North Point Press.

Nerz, Ryan. 2006. Eat This Book. New York: Saint Martin's Griffin.

Simmel, Georg. 1990. The Philosophy of Money, second edition, edited by David Frisby and translated by Toim Bottomore and David Frisby. London: Routledge.

Smith, David Norman. 2001. "The Spectral Reality of Value: Sieber, Marx, and Commodity Fetishism.” Marx's Capital and Capitalism; Markets in a Socialist Alternative, Research in Political Economy (19): 47-66.

Webber, Michael J. and David L. Rigby. 1996. The Golden Age Illusion: Rethinking Postwar Capitalism. New York: The Guilford Press.

Weber, Max. 1958. The Protestant Ethic and the Spirit of Capitalism. New York: Charles Scribner's Sons.

Tillich, Paul. 1955. The New Being. New York: Charles Scribner's Sons.

Žižek, Slavoj. 2008. In Defense of Lost Causes. London: Verso. -----. 2002. Welcome to the Desert of the Real. London: Verso. -----. 2001. On Belief. London: Routledge. 
